Firms' Investment under Financial Constraints: A Euro Area Investigation

Roman Kozhan and Rozalia Pal 


\title{
Firms' Investment under Financial Constraints A euro area investigation ${ }^{(1)}$
}

\author{
Rozália Pál ${ }^{(2)}$ \\ European University Viadrina
}

\author{
Roman Kozhan $^{(3)}$ \\ The University of Warwick
}

\begin{abstract}
In this paper we describe a model of optimal investment of various types of financially constrained firms. We show that the resulting relationship between internal funds and investment is non-monotonic. In particular, the magnitude of the cash flow sensitivity of the investment is lower for firms with credit rationing compared to firms that are able to obtained short-term external financing. The inverse relationship is driven by the leverage multiplier effect. A positive cash flow shock increases the short-term borrowing capacity of the firm, which in turn has a positive effect on investment and firm's growth. Moreover, the leverage multiplier effect is the highest for firms relying on short-term credits and it is lower for firms that are able to obtain long-term financing. Analysing a large euro area data set we find strong empirical support for our theoretical predictions. The results also help to explain some contrasting findings in the financial constraints literature.
\end{abstract}

Keywords: financing constraints, growth, investment, cash flow sensitivity JEL classification: D92, G3, G32

1) The paper draws from a project on financial constraints in the euro area, conducted while Rozália Pál was visiting the European Central Bank (ECB). We would like to thank the hospitality and research support of the ECB. The provided comments and suggestions of Annalisa Ferrando, Francesco Drudi, David Marqués Ibañez, Martin T. Bohl, Petra Köhler-Ulbrich and Peter Drejer are gratefully acknowledged.The opinions expressed herein are those of the authors and do not necessarily reflect those of the ECB.

2) Postgraduate Research Programme "Capital Markets and Finance in the Enlarged Europe", European University Viadrina, Große Scharrnstraße 59, 15230 Frankfurt (Oder), Germany, Phone: +49 3355534 2987, Fax: +49 3355534 2959, e-mail: pal@euv-frankfurt-o.de

3) Corresponding author. Warwick Business School, The University of Warwick, Coventry, CV4 7AL, UK, Phone: +442476524118, e-mail: Roman.Kozhan@wbs.ac.uk 
Understanding firms' investment decisions under imperfect market conditions is one of the central issues of financial economics. Studying firm's investment in such environment can provide insight into the dynamics of its growth as a function of internal and external financial sources. In the presence of financing constraints the firms investment vary not only with the availability of the profitable investment projects, but also with the internal funds (see Fazzari et al., 1988). Consequently, the severity of the financing constraints has been proposed to be measured by the magnitude of the cash flow sensitivity of investment.

However, there is debate on the interpretation of the sensitivity in the light of the financing constraints. Different conclusions are taken mostly because of the different ways of a-priori classification in financially constrained and unconstrained groups. One way to classify firms, proposed by Fazzari et al. (1988), is to consider them a-priori as constrained if they pay low dividend payout ratio. The estimated cash flow sensitivity of this group of firms is interpreted as an evidence of financing constraints. The lower sensitivity is taken as an evidence of the less severe financing conditions. ${ }^{1}$ Another possible classification is to define as financially constrained those firms that are in violation of debt covenants, have been cut out of their usual source of credit, are negotiating debt payments, or declare that they are forced to reduce investments because of liquidity problems (see Kaplan and Zingales, 1997). The classification of Kaplan-Zingales is based on the managers' report on operations, capital resources and liquidity (qualitative information) and financial statements and notes (quantitative information). Contrary to previous results, they document the highest cash flow sensitivity for least constrained firms. In a recent study, Moyen (2004) shows, constructing a simulated sample, that both results can be replicated just by changing the a-priori classification.

In this paper we continue to investigate the relationship between financing conditions and the sensitivity measure and propose another and more realistic classification of firms. First,

\footnotetext{
${ }^{1}$ Supporting results with alternative classifications are summarised in the literature overview presented by Schiantarelli (1995) and Hubbard (1998).
} 
we argue that in the real world it is hard to identify a group of firms in the absence of the financing constraints. Kaplan and Zingales (1997) also argue that just considering the external relative to the internal costs of financing we could hardly find any unconstrained firm. Consequently, we focus on the severity of the constraints instead of its absence or presence. We model the firms' cash flow sensitivity of total investment with respect to the reliance on the external financial sources. Further on, we differentiate firms relying mostly on short-term credits from those that are able to access long-term external sources assuming that long-term debt is more preferable for investments whenever it is available.

Some firms forgo investment rather than access capital markets. Consequently the firm will under-invest relative to its first best level. The reasons behind can be diverse, e.g. firm decide not to take the credit because of the high cost, managerial agency problem, or not wishing to provide private information on their projects to the financing institutions. Firms can face the credit rationing resulting from asymmetric information, moral hazard, adverse selection, costly state verification or low level of tangible assets ${ }^{2}$. Therefore, we provide a special attention to such group of firms that rely exclusively on their internal sources, considering them under the worst financing conditions.

Firms with a financing need (lower cash flow than investment value) access external financing sources whenever is possible in order to carry out their investment projects. However the variability in internal sources, especially a negative shock, increases not only the likelihood that a firm will need additional external sources but it also decreases the likelihood to obtain further external financing or to get it with higher cost due to increasing risk (see Minton and Schrand (1999)). In such a case both borrowing and investment become endogenous. An increase in cash flow results in a higher borrowing capacity, which in turn allow for higher investment and growth (see also Carpenter and Petersen (2002), Almeida, Campello and

\footnotetext{
${ }^{2}$ For theoretical discussion see Stiglitz and Weiss (1981), Williamson (1986), Bester (1985), Jaffee and Russell (1976), Sharpe (1990).
} 
Weisbach (2004), Almeida and Campello (2006), Lin (2007)). Consequently, we expect a higher sensitivity of levered firms compared to those relying exclusively on internal sources. Moreover, we argue that the leverage multiplier effect associated with the endogenous change deterioration of the firm's credit capacity following the negative cash flow shock is the highest for those constrained firms who need to negotiate periodically their external sources (financing through short-term credits). Firms that are able to obtain long-term debt are assumed to be the least constrained or even unconstrained firms (being defined as those firms that despite of some market imperfections all of their positive net value projects can be financed). We expect lower cash flow sensitivity for such firms compared to those that are financed by short-term borrowings. The borrowing capacity of firms able to obtain long-term debt we assume to be determined by factors less related to the current liquidity, but more long-term indicators such as credit history accumulated during the past years, stock market performance, bank-firm relationship, size, etc. In such case the multiplier effect is reduced or completely disappears. Still, the external funds could be insufficient for all of their positive net present value (NPV) projects and each additional cash flow would have a positive direct effect on the investment and growth. In optimal case, when internal and external funds are sufficient for all of their investment projects, investment should not vary with the internal funds. Taking in consideration both direct and indirect effects, we expect the cash-flow sensitivity of investments is to be the lowest for firms with long-term borrowing.

We test the predictions of the theoretical model using a euro-area sample. Borrowings from financial institutions play a special role in the European financial system. First, contrary to the American system, the European financial system is more bank than market oriented ${ }^{3}$. Private firms do not have the option to increase their capital trough new issue of shares (around $70 \%$ of our sample) and those listed on the market rely also on the credits obtained from

\footnotetext{
${ }^{3}$ In 2004, bank loans represented around $90 \%$ of the total debt flows to non-financial corporations in the euro area. The stock market capitalization at the end of 2003 in Euro Area was 73.4\%, which is significantly lower than the US capitalization of $129.6 \%$ of GDP (source: World Federation of Exchanges).
} 
financial institutions as the primary source ${ }^{4}$. Second, in line with the pecking order theory of Myers (1984) and Myers and Majful (1984), only firms, that are not able to increase their leverage, issue shares. Our firm classification relies on quantitative information taken from balance sheets and profits and lost statements, allowing the reclassification of firms' financial status each period. However the final analysis is in a dynamic framework and the firms' status in the whole period is determined conditional on its yearly changes.

We find strong empirical support for our predictions that for firms with no access to external financing sources an additional euro of internal cash flow results in less than a euro total investment in fixed and non-cash current assets. For partially constrained firms, which have access to external financial market but with certain binding conditions in sense that they are able to obtain only short-term credit, an additional euro generate slightly more than an additional one euro caused by the leverage multiplier effect. And finally, firms with available long-term borrowing face lower investment sensitivity on internal financing. Considering the classifications of the previous literature, our first group of firms that relies exclusively on internal finance have similar characteristics to those defined as constrained by the $\mathrm{KZ}$ index, Moyen's constrained model and Cleary's index (see Kaplan and Zingales (1997), Moyen (2004) and Cleary (1999)). Our results are similar to the findings of these studies, i.e. firms relying on internal sources (identified as constrained) face a lower sensitivity than those that are able to borrow. The lower sensitivity of long-term borrowing firms compared to the short-term borrowing firms is more in line with the Fazzari et al. (1988) findings, i.e firms facing higher asymmetric information problems and consequently not able to satisfy the conditions for longterm borrowing, have higher cash flow sensitivity. Hence, we present evidence for the two contradictory predictions of the literature, showing that they are rather complementary.

\footnotetext{
${ }^{4}$ For a more detailed description of the European financial system see Ehrmann et al (2001) and Hartmann et al. (2003).
} 
The paper is organized as follows. The next section presents the related literature of non-monotonic behaviour of investment-cash flow sensitivity. In Section 3 the theoretical model is presented. Section 4 describes the data and sample selection. In Section 5 the empirical test of the theoretical model's predictions is described. Main conclusions are summarised in the final section.

\section{Related literature}

On the theoretical basis there is no sufficient condition for monotonicity in the cash flow sensitivity of investments with respect to firms financing conditions. A higher sensitivity of corporate investment to cash flow is not sufficient evidence for more severe financing constraints (see Kaplan and Zingales $(1997,2000)$ ). Couple of recent papers present theoretical models supporting the non-monotonous sensitivity, however there is less clear way about its pattern, especially on the empirical level.

Cleary, Povel and Raith (2003) present a non-monotonic relationship between investment and cash flow. They show that firms with negative cash flow or zero dividends have the lowest sensitivity and it is the highest for firms with moderate cash flow or dividend. For the firms with the highest cash flow or dividend, which they considered as unconstrained, a lower sensitivity is estimated. Boyle and Guthrie (2003) present a dynamic model of investment distorted by costly external financing. They look at the relationship of investment timing and financing constraints showing that financing constraints can not only discourage investment, but also accelerate it, resulting in sub-optimal early investments. More importantly, an increase in cash has a smaller positive effect on the investment for constrained firms with low-cash than it does for constrained firms with high-cash. Dasgupta and Sengupta (2002) investigate with the help of a multi-period version of a standard moral hazard model the case when the firms have the option to allocate their liquidity inter-temporally. Their results are differing from the previous two studies. They argue that the responsiveness of investment to 
changes in liquidity is the highest for low liquidity firms, least for intermediate liquidity firms and intermediate for the high liquidity firms. Ozkan (2002) investigates the behaviour of research and development investment and shows it is more sensitive to internal finance for financially constrained firms than for financially unconstrained firms in the US manufacturing sector. However, Moyen (2004) shows that the value of cash flow, just as the dividend payout ratio used for a-priori classification is not appropriate to distinguish firms facing different financing conditions.

Moyen (2004) compares the dynamic model of unconstrained relative to constrained firm and he defines constraints based on their access to financial markets. They predict a higher investment cash-flow sensitivity of unconstrained firm, explained by the leverage effect. In their model only unconstrained firms can issue debt and they explain the higher sensitivity by the effect of debt financing on investment that is not taken into account by the regression specification. Carpenter and Petersen (2002) provide also a theoretical model for the leverage multiplier effect. They show that the leverage effect occurs when firms' access to debt depends on the collateral and each additional dollar of internal finance should generate slightly more than one additional dollar of growth. Similar to this explanation, Almeida and Campello (2006) develop a theory explaining that sensitivities will decrease with financial constraints, so long as firms are not entirely unconstrained. They explain the decreasing sensitivity of investment by the cash flow borrowing capacity. They show that investment-cash flow sensitivities are increasing in the degree of tangibility of constrained firms' assets and for entirely unconstrained firms the investment-cash flow sensitivities drop to zero. This implies that the relationship between capital spending and cash flows is non-monotonic.

Our results are in line with the Carpenter and Petersen (2002) and Almeida and Campello (2006) theoretical model predictions. Since Almeida and Campello (2006) show that the multiplier effect is increasing with project's tangibility, we show that such multiplier effect depends on the type of borrowing. We contribute to the literature of non-monotonic sensitivity, 
by differentiating the firms with short versus long-term financing. The endogenous multiplier effect increases the sensitivity of short-term borrowing firms relative to those that rely exclusively on internal financial sources. However, for those firms that are able to get longterm debt, the borrowing capacity is less dependent on the current cash flow shocks, but rather by "long-term" firm characteristics, like credit history, size and bank-firm relationship. In this case the indirect effect of cash flow on investments is less significant or even disappears. In addition, the direct effect of cash flow is expected to be less significant, since firms are able to make the long-term investment plans relying on long-term borrowings, weakening the reliance of investment on internal financing. The non-monotonic relationship of the theoretical literature relies partially on the existence of the totally unconstrained firms. Contrary to simulated sample, where unconstrained firms by definition have zero sensitivity, in real world none of the firms operate in perfect market conditions. The non-monotonic relationship theoretically derived in this paper is valid under the conditions of market imperfections and instead of perfectly unconstrained firms, that we consider unrealistic, we define firms with the best financing conditions those that are able to obtain the cheaper long-term external financing.

\section{Theoretical model}

In order to discuss the investment-cash flow sensitivity in the light of financial constraints let us give some more clear distinction of constrained firms. As it was already mentioned before, it is quite difficult to find in real world a group of absolutely unconstrained firms. It looks more realistic to determine the degree of the financing constraints based on the accessibility to different types of external financial sources. A firm is assumed to be absolutely constrained if it cannot issue or take any debt and its own internal sources are not enough to cover the optimal investment value (a firm which can self-finance all positive net present value projects is considered to be unconstrained). We consider a firm to be partially constrained if it 
has no possibility to issue or contract long-term debts but can rely on the short-term credits. And the least constrained firms are those that are able to issue or contract debts with long-term maturity. Investment project financing is always preferable the long-term borrowings rather than short-term borrowings due to the renegotiation costs and the risk of early liquidation.

We consider the model with a firm that will finance a long-term project (two periods in this context). The project's investment starts at time 0 and at the end of the second period the firm collects the revenues $F\left(I_{0}\right)$, where the production function $F: R^{+} \rightarrow R^{+}$is twice differentiable strictly concave (i.e. $\left.F^{\prime \prime}<0\right)$ and it is increasing $\left(F^{\prime}>0\right)$. There are two alternative sources of financing:, that is internally by using the cash flow (CF) and externally by borrowing funds (D) from creditors. We also assume that the firm cannot invest into the project the whole amount of the cash flow. For liquidity reasons it saves $\alpha C F$, where $\alpha<1$, under the form of cash or highly liquid assets.

Let us consider now the investment policies of the unconstrained and our three types of constrained firms.

Unconstrained firms with sufficient internal sources: The optimal investment can be calculated as the solution of the profit maximization problem.

$$
F\left(I_{0}\right)-I_{0} \rightarrow \max , I_{0} \leq(1-\alpha) C F
$$

This implies that the optimal investment of the firm is $I_{0}^{l}=I^{*}$ if $C F \geq \frac{I^{*}}{1-\alpha}$, where $I^{*}=\left(F^{\prime}\right)^{-1}(1)$ is the first-best investment - the solution of the unconstrained maximization problem $F\left(I_{0}\right)-I_{0} \rightarrow \max$. In this case we implicitly suppose that the firm can issue debt but does not do because it has enough internal sources to finance its project. Consequently, the cash flow sensitivity of the investment under no financing constraints is:

$$
\operatorname{Sens}_{l}=\frac{\partial I_{0}^{l}}{\partial C F}=0
$$


I. Absolutely constrained firms: Internal sources are not sufficient, i.e. its cash flow available for investment is less than the first best investment, $(1-\alpha) C F<I^{*}$. This group of firms cannot issue any debts. The profit function $F\left(I_{0}\right)-I_{0}$ is increasing on the interval $\left(0, I^{*}\right)$ (see Figure 1) and the maximization problem of this type of firm can be written as:

$$
\begin{aligned}
& F\left(I_{0}\right)-I_{0} \rightarrow \max , \\
& I_{0} \leq(1-\alpha) C F
\end{aligned}
$$

[Insert Figure 1 here]

Its solution for the amount of investment is: $I_{0}^{a}=(1-\alpha) C F$, and the investment-cash flow sensitivity is:

$$
\operatorname{Sens}_{a}=\frac{\partial I_{0}^{a}}{\partial C F}=1-\alpha<1
$$

II. Partially constrained firms: The insufficient internal sources, $C F<\frac{I^{*}}{1-\alpha}$, can be compensated by the issue of short-term debts. Firms financed by short-term debts need to renegotiate its credit contracts at time 1 or to find another credit in order to pay the financial obligations. We assume that the negotiation costs are fixed and smaller than the saved amount of cash, $\alpha C F$, so these reserves can be used at time 1 for contract renegotiation.

We assume that borrowing capacity is a function of the project tangibility (see also Carpenter and Petersen (2002) and Almeida and Campalo (2006)). The project can be liquidated at time 1 and its liquidation value is equal to $q I_{0}$, with $q<1$. Due to the risk of the project's default the bank is not willing to lend more than the liquidation value of the project plus the cash savings of the firm. In this case the firm is faced with a debt constraint of the form: $D \leq \alpha C F+q I_{0}$. We assume that the maximum total financing of the partially 
constrained firm is $(1-\alpha) C F+D_{\max }<I^{*}$ and the profit function, defined as $F\left(I_{0}\right)-I_{0}$ is increasing on the interval $\left(0, I^{*}\right)$. When $I=I^{*}$, the firm is assumed to have an infinitely elastic borrowing capacity and consequently enter the category of least constrained firms (III). The maximization problem of the partially constrained firms is:

$$
\begin{aligned}
& F\left(I_{0}\right)-I_{0} \rightarrow \max , \\
& I_{0} \leq(1-\alpha) C F+D, \\
& D \leq \alpha C F+q I_{0}
\end{aligned}
$$

We conclude that the optimal investment for the partially constrained firms is $I_{0}^{p}=\frac{C F}{1-q}$ and the investment-cash flow sensitivity of this type of firm equals: $\operatorname{Sens}_{p}=\frac{\partial I_{0}^{p}}{\partial C F}=\frac{1}{1-q}>1$.

III. Least constrained firms: Firms with available long-term debts do not face the problem of renegotiation risk and do not pay the fixed costs of the credit contract at time 1 . For this type of firms the borrowing capacity is assumed to be less dependent on the project tangibility, but rather on other characteristics, like size, firms' tangibility, credit history, quotation on the stock market or bank-firm relationship. Technically, we assume that: $\frac{\partial B(C F)}{\partial C F}=q^{\prime}<q$

Thus, the least constrained firm solves the maximization problem:

$$
\begin{aligned}
& F\left(I_{0}\right)-I_{0} \rightarrow \max , \\
& I_{0} \leq(1-\alpha) C F+D, \\
& D \leq B(C F) .
\end{aligned}
$$

The optimal investment $I_{0}^{l}=I^{*}$ if $(1-\alpha) C F+B(C F) \geq I^{*}$ (the global maximum $I^{*}$ of the function $F\left(I_{0}\right)-I_{0}$ lies within the constraint interval $(0,(1-\alpha) C F+B(C F))$ and $I_{0}^{l}=(1-\alpha) C F+B(C F)$ if $(1-\alpha) C F+B(C F)<I^{*}$. Hence, the optimal investment-cash flow sensitivity of the least constrained firm can be described as: 


$$
\text { Sens }_{l}=\frac{\partial I_{0}^{l}}{\partial C F}=\left\{\begin{array}{cc}
0, & (1-\alpha) C F+B(C F) \geq I^{*} \\
1-\alpha+q^{\prime}, & \text { otherwise }
\end{array}\right.
$$

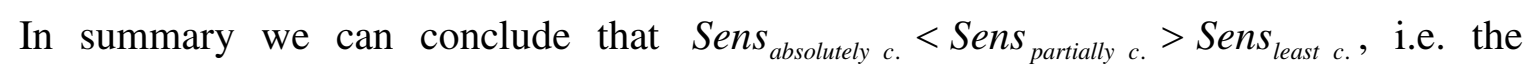
partially constrained firms are expected to have always the highest sensitivity. Firms relying on the long-term debts are expected to have the lowest sensitivity, however it depends on the percentage of firms that are able to finance most of their positive net value projects with the help of external financing. Our model shows a non-monotonic investment-cash flow sensitivity with respect to financing constraints even in the case when all firms faces some underfinancing problem (the direct effect of cash flow on investment is always present for the companies with underfinanced projects).

\section{Data}

\subsection{Sample construction}

We use a comprehensive database of euro area firms collected from the AMADEUS database of Bureau van Dijk. Amadeus contains financial information on about 2.6 millions private and publicly owned firms across euro area countries. Data is created by collecting standardised data received from vendors of each European country. In addition to financial information, the 4-digit NACE code, which is the European standard of industry classification, is also given. We select for our study only those firms that provide the consolidated balance sheets resulting in a sample of about 26,000 firms. The consolidated annual accounts are selected because these are considered to be the most suitable format for providing information about the financial situation of the parent company since the true financial boundaries of firms are at group level and not at individual plants. It takes in consideration the financial interest and the net assets owned by the parent in subsidiaries that will contribute to future earnings and dividends. Additionally, the consolidated accounts make our study more comparable across the results of the previous literature. 
The time period covered is 1990-2004, however we exclude the first four years because of the poor coverage and an additional year is lost by constructing the variables of interest as the first difference of the balance sheet items. We exclude firms operating in financial services industries (Nace code 65 and 66) because its financial ratios are not comparable to those of non-financial companies. In addition, we drop several country-specific industries, like the Agriculture (Nace code 1), Forestry (Nace code 2), Fishing (Nace code 5) and Mining (Nace code 10-14) industry sectors. Finally, we drop the government/public sector, Education, Health and social sector like activities of organizations, private households and extra-territorial organizations, and firms that cannot be classified (NACE codes 75, 80, 85, 91, 92, 95 and 99).

We apply several quality checks on the data. Only those firms are selected that provide information on the total assets and sales. The sample size is further reduced after checking the reported balance-sheet items of selected firms to be positive and that the sum of the subcategories of a balance-sheet item not to differ more than $5 \%$ from the reported value of the item. Finally, we exclude firms that are inactive. We apply a $1 \%$ trimming of the variables of main interest: logarithm of total assets, total assets growth, sales growth, total investment, cash flow to beginning of period total assets and short/long term borrowings to the beginning of year total assets. We retain only those firms that report data for, at least, three consecutive years. The main sample consists of 5,131 firms with 31,499 observations (for a detailed sample selection see Appendix).

Amadeus is especially useful because of its large coverage of both public and private firms ( $80 \%$ of total sample), however it faces some limitations. The coverage varies across euro area countries reflecting the peculiarities of European accounting legislation and its heterogeneity across countries. For example, Greek firms do not provide consolidated items and data on Irish firms were filtered out by the quality controls due to the low coverage. Austrian and Luxembourgian firms has a very low coverage. The Netherlands and Finland are over-represented due to statutory reporting requirements of the consolidated statements. 
Countries such as France, Italy and Spain are well covered by the sample (for a detailed crosscountry coverage of the sample see Appendix).

\subsection{Firms' classification}

While there is a consensus to consider financially constrained firms those that face difficulties in obtaining external finance, there is no clear way to identify these firms a-priori and the posterior sensitivity measures are influenced by the alternative a-priori classification. Just as Kaplan and Zingales (1997) argue, the definition of financial constraints based on the cost of internal and external financing is the most precise one but also the broadest as well. Based on this definition almost all firms can be classified as constrained, just considering the transaction costs of external financing. However there is a significant difference among firms with respect to their accessibility to external financing, which in turn affect their corporate investment policy and their growth. Our classification do not measure the internal relative to external costs but it capture cross-sectional differences in financing conditions defined as the availability of the external financial sources. Since all firms face the imperfect market conditions on some degree we propose a new classification instead of the traditional constrained-unconstrained classification. We identify three different types of firms: I) firms relying mostly on internal financial sources noted as absolutely constrained firms, II) firms relying on short-term external sources with maturity less than one year, noted as partially constrained, and III) firms relying on external financial sources in form of long-term borrowing with maturity above one year, considered as the least constrained firms. We classify firm-years in the first category, only when there is a sign of constraints, i.e. of the firm facing a financing need (higher investment value than current cash flow) but despite of this it cannot get external sources and needs to use the cash savings from the previous periods or it is even forced to liquidate its assets. We assume that firms with long-term projects would always prefer longterm instead of short-term borrowings because of the additional renegotiation costs and additional renegotiation risk that would force early liquidation of the investment project. 
Moreover, firms with higher borrowing costs tend to use less external finance than firms under favourable condition. However, we are not able to determine precisely, whether such firms with long-term borrowings are able to finance all of their positive net value projects but we can expect them to be closer to their optimal investment than those firms belonging to the other previously defined two groups and consequently, we can consider them the least constrained firms. Table 1 summarizes the criteria used in the classification and the cross-groups firm-year distribution.

[Insert Table 1 here]

After having classified each observation we apply a dynamic view of constraints. For this, we look at the characteristics used as classification criteria to be present for minimum of three consecutive years and in the most of the available years of the given company (total number of years divided by two plus one). In order to classify a firm as absolutely constrained, the majority of its firm-years but minimum of three consecutive years should satisfy the condition of exclusive reliance on internal financial sources despite of the financing need or they liquidate their assets. The firm is considered as partially constrained, if minimum of three consecutive years and in majority of its available years was categorised as partially or absolutely constrained. The least constrained firms are those that are not included in the previous two categories and consequently for such firms the financial constraints do not persist for more than half of the available years and less than 3 consecutive years. The final outcome of the classification is presented in Table 2 and the regression analyses are based on this dynamic firm classification.

[Insert Table 2 here] 


\section{Empirical test}

To gain some first insight into the firms' characteristics and their financing condition, key characteristics of the three firm-groups of the three groups are reported in Table 3. Differences in mean values of the variables among the firm-groups are tested based on the $t$ statistic.

[Insert Table 3 here]

The first variable presented in Table 3 indicates that firms that rely less intensively on external financing are relatively smaller firms. The growth of total assets $\left(2^{\text {nd }}\right.$ variable) is significantly higher for the firms with financial debt. Less risky firms get better financing, thus have less impediment in their growth. This relationship is important with respect to one of the main critic addressed to the sensitivity measure. Previous studies emphases that the magnitude of the sensitivities, which should measure the presence of financing constrained is actually reflecting future investment opportunities and it is higher for growing firms (see Ericson and Whited (2000), Alti (2003), Bond et al. (2004)). Thus the cash flow sensitivity could reflect the future investment opportunity, not efficiently captured by other proxies like Tobins' Q or sales growth. If the hidden investment opportunities would rule the investment-cash flow sensitivity of our sample, we should estimate a monotonic increase in sensitivity from absolutely to least constrained firms. If is any distortion caused by future investment opportunity, this would result in a higher increase of sensitivity of least constrained firms. A higher growth of the relatively less constrained firms has been documented also by Cleary (1999) and Whited and Wu (2004). They classify firms based on the dividend cuts and an index measuring the shadow cost associated with raising new equity (the cost of external finance relative to internal finance), respectively. 
The significantly higher sales growth ( $3^{\text {rt }}$ variable) of less constrained firms could be specific for the euro area firms. The euro area of the given period is characterised by a progress towards integration of financial system, not only in the area of money markets but also in bond markets, equity markets and banking. Related policy initiatives provide the opportunity for both new- and well-established firms to new directions of development. ${ }^{5}$ This mean that possible investment projects are above the internal financial sources and any additional external financing is able to increase their productivity and sales. Mizen and Vermeulen (2005) suggest using sales growth as a-priori classification criteria for some European firms, since the high sales' growth could be an indicator of financial health and future profitability that opens up access to external financing.

The lower cash flows ( $4^{\text {rt }}$ variable) of absolutely constrained firms confirm our assumption that the negative or zero borrowings are caused by the difficulties in obtaining external sources and not because of the abundant cash flow that is enough to finance all the projects. The yearly changes in the amount of short- and long-term credits $\left(5^{\mathrm{ft}}\right.$ and $6^{\text {th }}$ variables) are the proxies of the new external sources used as a classification criteria and the mean values reflect the outcome of the firms' classification. More importantly, the leverage $\left(7^{\text {th }}\right.$ variable) is higher for less constrained firms, indicating that these firms rely on external financial sources more intensively even in the period before the sample time-period. The lower leverage of the more constrained firms is in line with the findings of Faulkender and Petersen (2003). They argue that the availability of incremental capital depends on the risk of the firm's cash flows and characteristics of the firm. Consequently, firms with barriers to some external sources are under-levered. The unconstrained firms simulated by Moyen (2004) take on more more debt than constrained firms since they can respond to income shocks by varying their debt level.

\footnotetext{
${ }^{5}$ For a more detailed description of the euro area financial structure integration see Hartmann, Maddaloni and Manganelli (2003).
} 
Based on the leverage ( $7^{\text {th }}$ variable) and the proxy for the cost of credits ( $8^{\text {th }}$ variable) we find that less constrained firms despite of the higher leverage face lower financing costs. The bankruptcy cost of leverage suggests a positive relationship, in sense that higher leverage increases the bankruptcy risk and the higher risk should be compensated by higher interest. However, reliable, less risky firms should be able to increase their leverage without increase in its costs. Our data suggest that on the one hand, firms with long-term borrowing are less risky firms and consequently they are able to increase their leverage with lower cost. On the other hand, firms with short-term borrowings and relying mostly on their internal sources in the selected period (absolutely constrained) are under-levered. Absolutely constrained firms pay the highest cost for the credit obtained prior to the sample period and this could also explain why they do not take any further credit obligations.

The principal specification that we use to test the prediction of the investment-cash flow sensitivity of the selected three types of firms is an error correction model and it is specified as follows:

$$
\begin{aligned}
& \frac{\operatorname{In} v_{i, t}}{T A_{i, t-1}}=\delta_{0}+\delta_{1} \frac{\operatorname{In} v_{i, t-1}}{T A_{i t-2}}+\delta_{2} \frac{C F_{i, t}}{T A_{i, t-1}}+\delta_{3} \Delta \log S_{i, t}+\delta_{4}\left[\log T A_{i, t-1}-0.8 \Delta s_{i, t-1}\right]+\sum \delta_{j} D_{\text {year }} \\
& +\sum \delta_{k} D_{\text {industry }}+\sum \delta_{l} D_{\text {country }}+\varepsilon_{i t},
\end{aligned}
$$

where the dependent variable is the total investment of the firm $i$ at time $t$, measured as the change in fixed and non-cash current assets plus depreciation divided by the beginning of period total assets. Total investment includes beside the fixed investments the investment in current assets. Hence, the sensitivity is not effected by the temporally fluctuations of the investments through the draw down of working capital (see Carpenter and Petersen (2002)). $C F_{i, t}$ denotes the current cash flow calculated as the profit for the period (profit after tax plus extraordinary profit) plus depreciation and $\Delta \log$ Sales $_{i, t}$ is the first difference of the logarithm of sales, the proxy for firms' investment opportunities. The regression is controlled for time-, 
industry- and country- effects by inclusion of the corresponding dummy variables, $D_{\text {year }}, D_{\text {industry }}$, and $D_{\text {country }}$ respectively and $\varepsilon_{i, t}$ is a random disturbance. Since we focus on both public and private firms (for which the market value is not available), the expected profitability is controlled, instead of the Tobin's Q, by current sales growth, specific to the error correction models used by previous literature (see for instance Bond et al. (2004), Fuss and Vermuelen (2004)). The sales growth, just as the cash flow - relative to the Tobin's Q - can capture relatively newer information obtained within the year about the running projects of the firm based on which the manager decides about the new investment and revise the target capital stock accordingly (for theoretical model see Alti (2003)).

Estimating the dynamic structure of the growth, the lag value of dependent variable is also used as an explanatory variable. In addition, the model includes the error correction term, constructed as the difference between logarithm values of total assets and sales in the first lags multiplied by the 0.8 (the estimated long-term relationship among sales and non-cash total assets).

Table 4 presents the mean, median, standard deviation, minimum and maximum values of the variables used for the regression. The median firm has a yearly investment representing $10 \%$ of the beginning of year total assets, which drops to $5 \%$ for absolutely constrained firms. The median firm has a cash flow of $9 \%$ of the beginning of period total assets and a sales growth of $6 \%$. The annual growth of net working capital counts on average $1.2 \%$ of the total assets. Mean and median values do not differ significantly and the minimum and maximum values suggests that none of the coefficient estimates of the regressions can be influenced by the presence of outliers.

[Insert Table 4 here] 
Based on the theoretical model, the quantitative predictions of the cash flow sensitivity of absolutely constrained firms is less than one. The only source of financing is represented by cash flow; however a part of it is reoriented to precautionary cash savings or credit repayments. For partially constrained firms the sensitivity is expected to be slightly higher than one resulting from the leverage multiplier effect. And finally, for the least constrained firms a lower cash flow coefficient is expected, caused by the favourable financing contract less dependent on current cash flow variation (indirect effect) and by the possibility that all long-term investment projects of the firm to be covered by the available financial sources (direct effect).

In Table 5 the regression results of the two-step system GMM estimates are presented. The t-statistics are reported in parenthesis. Firm-specific effects are first removed by calculating the first differences specific to the GMM estimation. The third lagged values of endogenous variables are valid instruments since there is no serial correlation in the timevarying component of the error terms of the equation. This condition is met, since the test for serial correlation in the first difference residuals is rejected based on the test for second-order autocorrelation (the first-order autocorrelation is expected due to model specification). The validity of the used instruments is also accepted based on the Hansen test of over-identifying restrictions.

[Insert Table 5 here]

In each of the three samples the cash flow coefficient is statistically significant and it strongly supports the quantitative predictions of the model. The point estimate for cash flow in the case of absolutely constrained firms is 0.96 . For the partially constrained firms the cash flow coefficients of 1.15 is consistent with the presence of the leverage multiplier effect. And for the least constrained firms the cash flow coefficient is again lower, with the point estimates 
of $0.79 .{ }^{6}$ This lower coefficient is consistent with the models' prediction that the better credit contracts should reduce the investment dependence on internal finance.

The coefficient of the sales growth is highly significant for least constrained firms and significant under $5 \%$ confidence level for the partially and absolutely constrained firms. The negative coefficient of the lagged dependent variable, however not statistically significant, suggests a mean-reversion of the investment rate. The error correction terms are negative as expected, however not statistically significant. As a robustness test we use an alternative specification for the error correction term and re-estimate the equation (1). The error correction term (Err.Corr.Term) is the first lagged estimated residuals of the equation:

$$
\log T A_{i, t}=\alpha+\beta s_{i, t}+\gamma_{i}+\varepsilon_{i, t}
$$

where $\log T A_{i, t-1}$ and $s_{i, t}$ refer to the logarithm of total assets and sales. $\gamma_{i}$ and $\varepsilon_{i, t}$ represent the firm fixed effects and a random disturbance, respectively. Results are presented in Table 6. The cash flow sensitivity of investment has the same pattern as in the case of previous estimation, with higher coefficient for partially constrained firms of 1.34 . The coefficient of absolutely and least constrained firms is about 0.95 . The coefficients of the error correction terms is higher, given that the value of the estimated residual is lower than the assets-sales difference, however statistically still not significant. We can conclude that using alternative error correction specification our main results of the cash flow sensitivity is not affected.

\section{Conclusions}

In this paper we develop a theoretical model that makes quantitative predictions about the magnitude of the cash flow-investment sensitivity in the light of financing constraints. Relying on a sample of more than 5,000 euro area firms we document a non-monotonic

\footnotetext{
${ }^{6}$ The magnitude of the sensitivity is higher than those presented in most of the financing constraints literature. his is simply caused by the fact that our dependent variable is the investment in total assets instead of the investment in fixed assets. The magnitude of the coefficient is more comparable with the results presented by Carpenter and Petersen (2002), using the firm's growth as a dependent variable.
} 
investment-cash flow sensitivity, which strongly support the models' predictions. The explanation for the higher sensitivity of partially constrained firms relative to the absolutely constrained is twofold. First, only a part of internal sources are invested, since there is a need of precautionary cash savings for liquidity reasons. Second, investments increase the borrowing capacity of the firm, so the amount of credits depends also on cash flow shocks. Through this indirect leverage effect, an additional dollar of internal finance will generate slightly more than an additional dollar of total investment. These findings are in line with the amplification effect of Almeida and Campello (2006) and the leverage effect presented by Carpenter and Petersen (2002) and Moyen (2004). Moreover, we identify a group of the least constrained firms able to borrow long-term cheap sources, for which the sensitivity is lower than those with less favourable credit contracts (only short-term borrowings are available). We find evidence that the favourable financing contracts are less dependent on current cash flow shocks (indirect effect) and/or some of these firms are able to finance most of their positive net value projects with the help of external financing but internal sources remain an important financing source proved by relatively strong direct effect. The non-monotonic relationship of the previous theoretical literature relies partially on the existence of the totally unconstrained firms with zero sensitivity. Contrary to simulated sample, where unconstrained firms by definition have zero sensitivity, in real world none of the firms operate in perfect market conditions.

The non-monotonic relationship proved in this paper is valid also under the conditions of market imperfections as showed by the three types of constrained firms. We provide both theoretical and empirical evidence for the non-monotonic investment-cash flow sensitivity from a new perspective. The estimated cash flow sensitivity of investment led us to conclude that financing conditions may determine investment and growth of the European firms. 


\section{References}

Almeida, Heitor and Murillo Campello, 2006, Financial constraints, asset tangibility, and corporate investment, NBER Working Paper No.12087.

Almeida, Heitor, Campello, Murillo and Michael Weisbach, 2004, The cash flow sensitivity of cash, The Journal of Finance, 59, 1777-804.

Alti, Aydogan, 2003, How sensitive is investment to cash flow when financing is frictionless? Journal of Finance 58, 707-722.

Arrelano, Manuel and Stephen Bond, 1991, "Some tests of specification for panel data: Monte Carlo evidence and an application to employment equations", Review of Economic Studies 58, 277-297.

Bester, Helmut, 1985, Screening versus Rationing in Credit Markets with Imperfect Information, American Economic Review 75, 850-855.

Blundell, Richard and Stephen R. Bond, 1998, Initial conditions and moment restrictions in dynamic panel data models, Journal of Econometrics, 87, 115-143.

Bond, Steve, Alexander Klemm, Rain Newton-Smith, Murtaza Syed and Gertjan Vlieghe, 2004, The roles of expected profitability, Tobin's Q and cash flow in econometric models of company investment, The Institute for fiscal studies, working paper No. 04/12.

Boyle, Glenn W. and Graeme A. Guthrie, 2003, Investment, uncertainty, and liquidity, Journal of Finance 58, 2143-2166.

Carpenter, Robert, and Bruce C. Petersen, 2002, Is the growth of small firms constrained by internal finance?, The Review of Economics and Statistics,84, 298-309.

Cleary, Sean, 1999, The relationship between firm investment and financial status, The Journal of Finance 54,673-692.

Cleary, Sean, Paul E. M. Povel and Michael Raith, 2004, The U-shaped investment curve: theory and evidence, Working Paper, CEPR. 
Dasgupta, Sudipto and Kunal Sengupta, 2002, Financial constraints, investment and capital structure: Implications from a multi-period model, Working Paper, Hong Kong University of Sience and Technology.

Ehrmann, Michael, Leonardo Gambacorta, Jorge Martinéz Pagés, Patrick Sevestre and Andreas Worms, 2001, Financial systems and the role of banks in monetary policy transmission in the euro area, ECB working paper No. 105.

Ericson, Timothy and Toni Whited, 2000, Measurement error and the relationship between investment and Q, Journal of Political Economy 108, 1027-1057.

Faulkender, Michael and Mitchell A. Petersen, 2003, Does the source of capital affect capital structure?, NBER working paper No. 9930.

Fazzari, Steven M., R. Glenn Hubbard, and Bruce C. Petersen, 1988, Financing constraints and corporate investment, Brookings Paper on Economic Activity 1, 141-195.

Fuss, Catherine and Philip Vemeulen, 2004, Firms' investment decisions in response to demand and price uncertainty, ECB working paper No. 347.

Hartmann, Phillip; Angela Maddaloni and Simone Manganelli, 2003, The Euro Area financial system: Structure, integration and policy initiatives, ECB working paper No. 230.

Hubbard R. Glenn, 1998, Capital market imperfections and investment, NBER working paper No. 5996.

Jafee M. Dwinght and T. Russell, 1976, Imperfect Information, Uncertainty and Credit Rationing, Quarterly Journal of Economics XC, 651-666.

Kaplan, Steven N., and Luigi Zingales, 1997, Do investment-cash flow sensitivities provide useful measures of financing constraints?, Quarterly Journal of Economics 112, 169-215.

Kaplan, Steven N., and Luigi Zingales, 2000, Investment-cash flow sensitivities are not valid measures of financing constraints, Quarterly Journal of Economics 115, 705-712.

Lin, Yi-Chen, The cash flow sensitivity of cash: evidence from Taiwan, Applied Financial Economics, 2007, 17, 1013-1024 
Minton, Bernadette and Chaterine Schrand, 1999, Does Cash Flow Volatility Affect Firm Value: Its Impact on Discretionary Investment and the Costs of Debt and Equity Financing, Journal of Financial Economics 54, 432-460.

Mizen, Paul and Philip Vermeulen, 2005, Corporate investment and cash flow sensitivity. What drives the relationship? ECB Working paper No. 485.

Moyen, Nathalie, 2004, Investment-cash flow sensitivity: constrained versus unconstrained firms, Journal of Finance 59, 2061-2092.

Myers, Stewart C., 1984, The capital structure puzzle, Journal of Finance 39, 575-592.

Myers, Stewart C. and Nicholas S. Majful, 1984, Corporate financing decisions when firm have investment information that investors do not have, Journal of Financial Economics 13, 187-221.

Ozkan, Neslihan, 2002, Effects of financial constraints on research and development investment: an empirical investigation, Applied Financial Economics, 2002, 12, 827834.

Schiantarelli, Fabio, 1995, Financial constraints and investment: a critical review of methodological issues and international evidence, Boston College working paper.

Sharpe, S., 1990, Asymmetric Information, bank lending and implicit contracts: A Stylised model of customers relationships, Journal of Finance 45, 1069-1087.

Stiglitz, J. and A.Weiss, 1981, Credit rationing in markets with imperfect information, American Economic Review 71, 393-410.

Whited, M. Toni and Guojun Wu, 2004, Financial constraints risk, Review of Financial Studies $14,529-544$.

Williamson, S., 1986, Costly monitoring, financial intermediation, and equilibrium credit rationing. Journal of Monetary Economics 18, 159-179. 


\section{Table 1. Firm-years' classification}

\begin{tabular}{ccccc}
$\begin{array}{c}\text { Financing condition } \\
(\% \text { from total })\end{array}$ & $\begin{array}{c}\text { Total } \\
\text { investment }\end{array}$ & $\begin{array}{c}\text { Financing } \\
\text { gap }\end{array}$ & $\begin{array}{c}\text { Changes in Long- } \\
\text { term debt }\end{array}$ & $\begin{array}{c}\text { Changes in } \\
\text { Short-term debt }\end{array}$ \\
\hline
\end{tabular}

Firm-years financed by internal capital (I.)
1. $(10 \%)$
$\geq 0$
$\leq 0$
$\leq 0$
2. $(19 \%)$
$<0$
$\leq 0$

Firm-years financed by short-term external capital (II.)
1. $(8 \%)$
$\geq 0$
$<0$
$<0$
2. $(24 \%)$
$\geq 0$
$\geq 0$
$\leq 0$
$>0$
3. $(3 \%)$
$<0$
$>0$

Firm-years financed by long-term external capital (III.)
1. $(20 \%)$
$\geq 0$
$<0$
$\geq 0$
2. $(16 \%)$
$\geq 0$
$\geq 0$
$>0$

Note: Static classification of firms based on their accounting characteristics.

\section{Table 2. Firms' classification}

\begin{tabular}{cccc} 
Final outcome & $\begin{array}{c}\text { No. of observation } \\
\text { (firm-years) }\end{array}$ & No. of firms & \% o firms \\
\hline Absolutely constrained firms (I.) & 6,709 & 1,112 & $21 \%$ \\
Partially constrained firms (II.) & 17,266 & 2,767 & $54 \%$ \\
Least constrained firms (III.) & 7,524 & 1,252 & $25 \%$ \\
\hline
\end{tabular}

Note: Summary statistics of final firms' classification based on the dynamics of financial constraints. 
Table 3. Summary statistics

\begin{tabular}{cccccc} 
Variables & Mean & Median & Std. Dev. & $\begin{array}{c}\text { P-value } \\
(I .=I I .)\end{array}$ & $\begin{array}{c}\text { P-value } \\
(I I .=I I I .)\end{array}$ \\
\hline 1. Firms' size (logarithm of total assets) & & & 0.00 & 0.00 \\
I. & 10.745 & 10.705 & 1.732 & & \\
II. & 11.198 & 11.041 & 1.725 & & \\
III. & 11.758 & 11.584 & 1.870 &
\end{tabular}

2. Firms' total investment to beginning of year total assets
I.
0.078
0.048
II.
0.130
0.099
0.187
III.
0.167
0.127
0.179
0.188

0.00

0.00

3. Sales' growth

$0.00 \quad 0.00$

$\begin{array}{cccc}I . & 0.036 & 0.029 & 0.202 \\ I I . & 0.072 & 0.060 & 0.176 \\ I I I . & 0.099 & 0.081 & 0.180\end{array}$

4. Cash flow to the beginning of year total assets

$0.00 \quad 0.00$
I.
0.088
0.079
0.077
II.
0.100
0.090
0.072
III.
0.114
0.102
0.075

5. Obtained long-term credit to the beginning of period total assets

$0.00 \quad 0.00$
$I$.
$-0.007$
0.00
0.044
II.
$-0.001$
0.00
0.058
III.
0.024
0.001
0.074

6. Obtained short-term credit to the beginning of period total assets

0.00
I.
$-0.003$
0.00
0.064
II.
0.016
0.002
0.082
III.
0.015
0.000
0.072

7. Leverage (total debt to total assets)

$0.00 \quad 0.00$
I.
0.143
0.080
0.165
II.
0.230
0.212
0.163
III.
0.257
0.245
0.186

8. Cost of credit (interest payments to total debt)

$0.00 \quad 0.00$

$\begin{array}{cccc}I . & 0.150 & 0.091 & 0.161 \\ I I . & 0.116 & 0.076 & 0.125 \\ \text { III. } & 0.098 & 0.065 & 0.115\end{array}$

Note: Firms' total investment is calculated as investment in fixed and current assets plus depreciation. Cash flow is defined as profit for the period plus depreciation. Sales growth is calculated as the first difference of the logarithm of annual sales. The obtained credits are calculated as the yearly change of the financial debt. Interest payments include all interest paid and similar charges in the given year. We assign the letter $I$. for absolutely constrained firms, $I I$. for partially constrained firms and $I I I$. for the least constrained firms. We test the hypothesis that the mean value of variables of one group is not significantly different across firm groups using a t-test. $\mathrm{P}$ values of t-test are presented in the last two columns. 


\section{Table 4. Summary statistics of variables used in regressions}

No. of Obs. Mean Med. Stand.Dev. Min. Max.

\begin{tabular}{|c|c|c|c|c|c|c|}
\hline \multicolumn{7}{|l|}{ All type of firms } \\
\hline$\frac{\operatorname{Inv}}{T A}_{i, t-1}$ & 31,434 & 0.13 & 0.10 & 0.19 & -0.36 & 1.47 \\
\hline$\frac{C F_{i, t}}{T A_{i, t-1}}$ & 31,499 & 0.10 & 0.09 & 0.07 & -0.17 & 0.45 \\
\hline$\Delta s_{i, t}$ & 25,129 & 0.07 & 0.06 & 0.18 & -0.82 & 1.29 \\
\hline $\log T A_{i, t-1}-0.8 s_{i, t-1}$ & 25,129 & 2.01 & 1.95 & 0.77 & -1.48 & 8.35 \\
\hline Err.Corr.Term & 25,129 & 0.011 & 0.011 & 0.002 & 0.010 & 0.029 \\
\hline \multicolumn{7}{|l|}{$I$} \\
\hline${\frac{\operatorname{In} v_{i, t}}{T A}}_{i, t-1}$ & 6,685 & 0.08 & 0.05 & 0.19 & -0.36 & 1.41 \\
\hline$\frac{C F_{i, t}}{T A_{i, t-1}}$ & 6,709 & 0.09 & 0.08 & 0.08 & -0.16 & 0.45 \\
\hline$\Delta s_{i, t}$ & 6,709 & 0.04 & 0.03 & 0.20 & -0.82 & 1.27 \\
\hline $\log T A_{i, t-1}-0.8 s_{i, t-1}$ & 5,278 & 1.81 & 1.76 & 0.76 & -1.48 & 3.49 \\
\hline Err.Corr.Term & 5,278 & 0.011 & 0.011 & 0.002 & 0.010 & 0.029 \\
\hline \multicolumn{7}{|l|}{$I I}$. \\
\hline${\frac{\operatorname{In} v_{i, t}}{T A}}_{i, t-1}$ & 17,242 & 0.13 & 0.10 & 0.18 & -0.36 & 1.47 \\
\hline$\frac{C F_{i, t}}{T A_{i, t-1}}$ & 17,266 & 0.10 & 0.09 & 0.07 & -0.17 & 0.45 \\
\hline$\Delta s_{i, t}$ & 17,266 & 0.07 & 0.06 & 0.18 & -0.81 & 1.29 \\
\hline $\log T A_{i, t-1}-0.8 s_{i, t-1}$ & 13,878 & 1.977 & 1.939 & 0.717 & -0.433 & 7.386 \\
\hline Err.Corr.Term & 13,878 & 0.011 & 0.011 & 0.002 & 0.010 & 0.023 \\
\hline \multicolumn{7}{|l|}{ III. } \\
\hline$\frac{\operatorname{Inv}}{i, t}_{T A}$ & 7,507 & 0.17 & 0.13 & 0.19 & -0.36 & 1.46 \\
\hline$\frac{C F_{i, t}}{T A_{i, t-1}}$ & 7,524 & 0.11 & 0.10 & 0.08 & -0.17 & 0.45 \\
\hline$\Delta s_{i, t}$ & 7,524 & 0.10 & 0.08 & 0.18 & -0.81 & 1.26 \\
\hline $\log T A_{i, t-1}-0.8 s_{i, t-1}$ & 5,973 & 2.24 & 2.16 & 0.85 & -0.34 & 8.35 \\
\hline Err.Corr.Term & 5,973 & 0.012 & 0.011 & 0.002 & 0.010 & 0.024 \\
\hline
\end{tabular}

Note: $\frac{\operatorname{Inv}}{T A}_{i, t-1}$ is the total investment of the firm at time it, measured as the change in fixed and noncash current assets plus depreciation divided by the beginning of period total assets. $C F_{i, t}$ denotes the current cash flow calculated as the profit for the period (profit after tax plus extraordinary profit) plus depreciation and $\Delta s_{i, t}$ is the first difference of the logarithm of sales. $\log T A_{i, t-1}$ and $s_{i, t-1}$ refer to the first lag of the logarithm of total assets and sales. The Er.Corr.Term is the first lagged estimated residuals of the equation $\log T A_{i, t}=\alpha+\beta s_{i, t}+\gamma_{i}+\varepsilon_{i, t}$, where $\log T A_{i, t-1}$ and $s_{i, t}$ refer to the logarithm of total assets and sales. $\gamma_{i}$ and $\varepsilon_{i, t}$ represent the firm fixed effects and a random disturbance, respectively. 


\section{Table 5. Error correction model - Two step estimates}

\begin{tabular}{|c|c|c|c|}
\hline Dependent variable: $\frac{\operatorname{In} v_{i, t}}{T A_{i, t-1}}$ & $I$. & $I I$. & III. \\
\hline Intercept & $\begin{array}{l}-0.295 \\
(-0.21)\end{array}$ & $\begin{array}{l}0.120 \\
(0.08)\end{array}$ & $\begin{array}{l}0.188 \\
(0.43)\end{array}$ \\
\hline$\frac{I n v_{i, t-1}}{T A_{i, t-2}}$ & $\begin{array}{l}-0.230 \\
(-1.26)\end{array}$ & $\begin{array}{l}-0.157 \\
(-1.03)\end{array}$ & $\begin{array}{l}-0.004 \\
(-0.04)\end{array}$ \\
\hline$\frac{C F_{i, t}}{T A_{i, t-1}}$ & $\begin{array}{c}0.960 \\
(2.71)^{* * *}\end{array}$ & $\begin{array}{c}1.153 \\
(3.68)^{* * *}\end{array}$ & $\begin{array}{c}0.793 \\
(2.21)^{* *}\end{array}$ \\
\hline$\Delta s_{i, t}$ & $\begin{array}{c}0.387 \\
(2.31)^{* *}\end{array}$ & $\begin{array}{c}0.264 \\
(2.09)^{* *}\end{array}$ & $\begin{array}{c}0.393 \\
(2.73)^{* * *}\end{array}$ \\
\hline $\log T A_{i, t-1}-0.8 s_{i, t-1}$ & $\begin{array}{l}-0.013 \\
(-0.24)\end{array}$ & $\begin{array}{l}-0.069 \\
(-1.43)\end{array}$ & $\begin{array}{l}-0.029 \\
(-0.97)\end{array}$ \\
\hline $\mathrm{N}$ & 5,266 & 13,860 & 5,962 \\
\hline Hansen test - $\chi^{2}$ (prob.) & $\begin{array}{c}43.0 \\
(0.30)\end{array}$ & $\begin{array}{l}48.1 \\
(0.15)\end{array}$ & $\begin{array}{c}40.2 \\
(0.42)\end{array}$ \\
\hline $\mathrm{AR}(1)-z$ statistic (prob.) & $\begin{array}{l}-2.56 \\
(0.01)\end{array}$ & $\begin{array}{l}-2.55 \\
(0.01)\end{array}$ & $\begin{array}{l}-4.44 \\
(0.00)\end{array}$ \\
\hline $\operatorname{AR}(2)-z$ statistic (prob.) & $\begin{array}{l}-0.78 \\
(0.44)\end{array}$ & $\begin{array}{l}-0.72 \\
(0.47)\end{array}$ & $\begin{array}{c}0.78 \\
(0.43)\end{array}$ \\
\hline
\end{tabular}

Note: We assign the letter $I$. for absolutely constrained firms, $I I$. for partially constrained firms and $I I I$. for the least constrained firms. Two-step system GMM estimates are presented with finite-sample correction to the two-step covariance matrix (robust standard errors). $\frac{\operatorname{In} v_{i, t}}{T A_{i, t-1}}$ is the total investment of the firm $i$ at time $t$, measured as the change in fixed and non-cash current assets plus depreciation divided by the beginning of period total assets. $C F_{i, t}$ denotes the current cash flow calculated as the profit for the period (profit after tax plus extraordinary profit) plus depreciation and $\Delta s_{i, t}$ is the first difference of the logarithm of sales. $\log T A_{i, t}$ and $s_{i, t}$ refer to the logarithm of total assets and sales. All regressions include a set of industry, time and country dummies (not reported). Instruments are the $3^{\text {rd }}$ lags of the dependent and independent variables. The $2^{\text {nd }}$ lag of the error correction term is used as an instrument only in the level equation. Industry and time dummies are also taken as strictly exogenous instruments for the level equation. t-statistics are reported in parenthesis. ${ }^{*}, * *$ and $* * *$ indicate statistical significance at the $10 \% .5 \%$ and $1 \%$ level, respectively. 


\section{Table 6. Robustness: alternative error correction term specification}

\begin{tabular}{|c|c|c|c|}
\hline Dependent variable: $\frac{\operatorname{In} v_{i, t}}{T A_{i, t-1}}$ & $I$. & $I I$. & III. \\
\hline Intercept & $\begin{array}{l}0.163 \\
(0.11)\end{array}$ & $\begin{array}{l}-0.418 \\
(-0.26)\end{array}$ & $\begin{array}{l}0.174 \\
(0.39)\end{array}$ \\
\hline$\frac{\operatorname{In} v_{i, t-1}}{T A_{i, t-2}}$ & $\begin{array}{l}-0.146 \\
(-0.80)\end{array}$ & $\begin{array}{l}-0.173 \\
(-1.15)\end{array}$ & $\begin{array}{l}-0.048 \\
(-0.49)\end{array}$ \\
\hline$\frac{C F_{i, t}}{T A_{i, t-1}}$ & $\begin{array}{c}0.959 \\
(3.11)^{* * *}\end{array}$ & $\begin{array}{c}1.341 \\
(4.55)^{* * *}\end{array}$ & $\begin{array}{c}0.951 \\
(3.01)^{* * *}\end{array}$ \\
\hline$\Delta s_{i, t}$ & $\begin{array}{l}0.141 \\
(1.09)\end{array}$ & $\begin{array}{c}0.268 \\
(2.13)^{* *}\end{array}$ & $\begin{array}{c}0.391 \\
(2.85)^{* * *}\end{array}$ \\
\hline Err.Corr.Term & $\begin{array}{l}-4.804 \\
(-0.31)\end{array}$ & $\begin{array}{l}-7.312 \\
(-0.99)\end{array}$ & $\begin{array}{l}2.524 \\
(0.39)\end{array}$ \\
\hline $\mathrm{N}$ & 5,266 & 13,860 & 5,962 \\
\hline Hansen test - $\chi^{2}$ (prob.) & $\begin{array}{c}49.1 \\
(0.13)\end{array}$ & $\begin{array}{l}41.6 \\
(0.20)\end{array}$ & $\begin{array}{c}45.1 \\
(0.15)\end{array}$ \\
\hline $\mathrm{AR}(1)-z$ statistic (prob.) & $\begin{array}{l}-2.64 \\
(0.00)\end{array}$ & $\begin{array}{l}-2.09 \\
(0.04)\end{array}$ & $\begin{array}{l}-2.79 \\
(0.01)\end{array}$ \\
\hline $\mathrm{AR}(2)-z$ statistic (prob.) & $\begin{array}{l}-0.95 \\
(0.34)\end{array}$ & $\begin{array}{l}-0.49 \\
(0.63)\end{array}$ & $\begin{array}{l}-0.75 \\
(0.46)\end{array}$ \\
\hline
\end{tabular}

Note: We assign the letter $I$. for absolutely constrained firms, $I I$. for partially constrained firms and $I I I$. for the least constrained firms. Two-step system GMM estimates are presented with finite-sample correction to the two-step covariance matrix (robust standard errors). $\frac{I n v_{i, t}}{T A_{i, t-1}}$ is the total investment of the firm $i$ at time $t$, measured as the change in fixed and non-cash current assets plus depreciation divided by the beginning of period total assets. $C F_{i, t}$ denotes the current cash flow calculated as the profit for the period (profit after tax plus extraordinary profit) plus depreciation and $\Delta s_{i, t}$ is the first difference of the logarithm of sales. The Err.Corr.Term is the first lagged estimated residuals of the equation $\log T A_{i, t}=\alpha+\beta s_{i, t}+\gamma_{i}+\varepsilon_{i, t}$, where $\log T A_{i, t}$ and $s_{i, t}$ refer to the logarithm of total assets and sales. $\gamma_{i}$ and $\varepsilon_{i, t}$ represent the firm fixed effects and a random disturbance, respectively. All regressions include a set of industry, time and country dummies (not reported). Instruments are the $3^{\text {rd }}$ lags of the dependent and independent variables. The $2^{\text {nd }}$ lag of the error correction term is used as an instrument only in the level equation. Industry and time dummies are also taken as strictly exogenous instruments for the level equation. t-statistics are reported in parenthesis. ${ }^{*}, * *$ and $* * *$ indicate statistical significance at the $10 \% .5 \%$ and $1 \%$ level, respectively. 


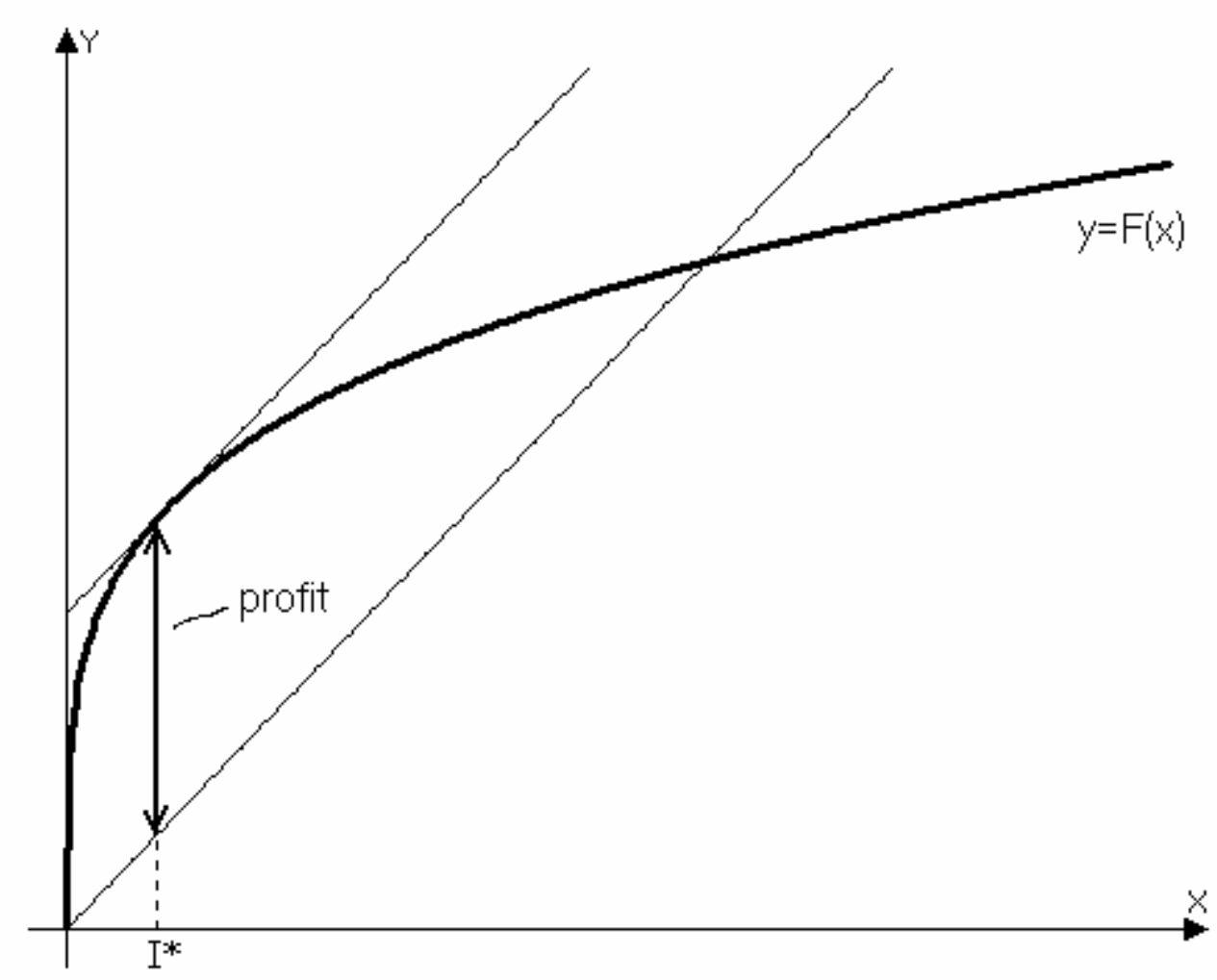

Figure 1. The profit function is increasing up to the first-best investment and decreasing afterwards. 


\section{Appendix:}

\section{Table A1. Sample selection}

$\begin{array}{ccc} & \text { Size } & \text { Size } \\ \text { Selection criteria } & \text { No. of firms } & \text { No. of firm-years } \\ & 1995-2004 & 1995-2004\end{array}$

1.

Non-financial sectors, excluding agriculture, forestry, fishing and mining, government sectors and undetermined sectors

(not in $\mathrm{A}, \mathrm{B}, \mathrm{C}, \mathrm{J}, \mathrm{L}, \mathrm{M}, \mathrm{N}, \mathrm{O}, \mathrm{P}$, Q) ${ }^{7}$

2.

Exclusion of firms with Inactive legal status ${ }^{8}$

3.

Firms with consistent balance sheet at $5 \%$ (i.e. $5 \%$ deviation is allowed) and cash and cash equivalent $\leq$ other current assets (when available)

4.

Trimming of the variables of main interest: logarithm of total assets, total assets growth, sales growth, total investment, cash flow to 14,152 65,434 beginning of period total assets and short/long term borrowings

5.

Exclusion of observations with missing growth variables (total assets and sales growth)-first year of each firm plus observations following a year gap

6.
Minimum of three consecutive years per company

\footnotetext{
${ }^{7}$ A-Agriculture and related service activities, B-Fishing, operation of fish hatcheries and fish farms, C-Mining and quarrying, J-Financial intermediation, L-Public administration and defence, compulsory social security, MEducation, N-Health and social work, O-Other community, social and personal service activities, P-Private households with employed persons, $\mathbf{Q}$ - Extra-territorial organisations and bodies

$8 *$ Selected firms with legal status defined as Active, Active (default of payments), Active (receivership) or not available. Excluded those under legal status defined as Bankruptcy, Dissolved, Dissolved (demerger), Dissolved (merger), In liquidation, Inactive (no precision), Credito incobrable, Naar buitenland, Not classified, Not defined, Removed.
} 
Table A2. Country coverage

\begin{tabular}{clcc} 
& & $\begin{array}{c}\text { Size } \\
\text { No. ofservations }\end{array}$ & $\begin{array}{c}\text { Percentage from } \\
\text { total }\end{array}$ \\
\hline 1. & Austria & 75 & $0 \%$ \\
2. & Belgium & 991 & $3 \%$ \\
3. & Finland & 6,893 & $22 \%$ \\
4. & France & 5,583 & $18 \%$ \\
5. & Germany & 1,661 & $5 \%$ \\
6. & Italy & 4,055 & $13 \%$ \\
7. & Luxemburg & 21 & $0 \%$ \\
8. & Netherlands & 8,616 & $27 \%$ \\
9. & Portugal & 621 & $2 \%$ \\
10. & Spain & 2,983 & $9 \%$ \\
\hline
\end{tabular}

\section{Table A3. Observations per years}

Size

No. of observations

\begin{tabular}{ccc}
\hline 1. & 1995 & 1,036 \\
2. & 1996 & 1,772 \\
3. & 1997 & 2,482 \\
4. & 1998 & 3,006 \\
5. & 1999 & 3,693 \\
6. & 2000 & 4,074 \\
7. & 2001 & 4,602 \\
8. & 2002 & 4,410 \\
9. & 2003 & 3,470 \\
10 & 2004 & 2,954 \\
\hline
\end{tabular}

Table A4. Firm distribution by market quotation

Size

Percentage from

No. of observations

1. Listed

6,993

total

2. Unlisted

24,506

$22 \%$

$78 \%$

Table A5: Industry distribution

\begin{tabular}{llcc} 
& & $\begin{array}{c}\text { Size } \\
\text { No. of observations }\end{array}$ & $\begin{array}{c}\text { Percentage from } \\
\text { total }\end{array}$ \\
\hline 1. & Construction & 2,475 & $8 \%$ \\
2. & Manufacturing & 8,817 & $28 \%$ \\
3. & Utilities & 2,343 & $7 \%$ \\
4. & Wholesale and retail sales & 7,326 & $23 \%$ \\
5. & Transport and communication & 1,947 & $6 \%$ \\
6. & Services (business activities, hotels & 8,591 & $27 \%$ \\
& and restaurants) & & \\
\hline
\end{tabular}




\section{List of other working papers:}

\section{8}

1. Roman Kozhan and Rozalia Pal, Firms' Investment under Financial Constraints: A Euro Area Investigation, WP08-07

2. Roman Kozhan and Mark Salmon, On Uncertainty, Market Timing and the Predictability of Tick by Tick Exchange Rates, WP08-06

3. Roman Kozhan and Mark Salmon, Uncertainty Aversion in a Heterogeneous Agent Model of Foreign Exchange Rate Formation, WP08-05

4. Roman Kozhan, Non-Additive Anonymous Games, WP08-04

5. Thomas Lux, Stochastic Behavioral Asset Pricing Models and the Stylized Facts, WP08-03

6. Reiner Franke, A Short Note on the Problematic Concept of Excess Demand in Asset Pricing Models with Mean-Variance Optimization, WP08-02

7. Alexandra Dias, Semi-parametric estimation of joint large movements of risky assets, WP08-01

\section{7}

1. Timur Yusupov and Thomas Lux, The Efficient Market Hypothesis through the Eyes of an Artificial Technical Analyst: An Application of a New Chartist Methodology to High-Frequency Stock Market Data, WP07-13

2. Liu Ruipeng, Di Matteo and Thomas Lux, True and Apparent Scaling: The Proximity of the Markov- Switching Multifractal Model to Long-Range Dependence, WP07-12

3. Thomas Lux, Rational Forecasts or Social Opinion Dynamics? Identification of Interaction Effects in a Business Climate Survey, WP07-11

4. Thomas Lux, Collective Opinion Formation in a Business Climate Survey, WP07-10

5. Thomas Lux, Application of Statistical Physics in Finance and Economics, WP07-09

6. Reiner Franke, A Prototype Model of Speculative Dynamics With Position-Based Trading, WP07-08

7. Reiner Franke, Estimation of a Microfounded Herding Model On German Survey Expectations, WP07-07

8. Cees Diks and Pietro Dindo, Informational differences and learning in an asset market with boundedly rational agents, WP07-06

9. Markus Demary, Who Do Currency Transaction Taxes Harm More: Short-Term Speculators or Long-Term Investors?, WP07-05

10. Markus Demary, A Heterogenous Agents Model Usable for the Analysis of Currency Transaction Taxes, WP07-04

11. Mikhail Anufriev and Pietro Dindo, Equilibrium Return and Agents' Survival in a Multiperiod Asset Market: Analytic Support of a Simulation Model, WP07-03

12. Simone Alfarano and Michael Milakovic, Should Network Structure Matter in Agent-Based Finance?, WP07-02

13. Simone Alfarano and Reiner Franke, A Simple Asymmetric Herding Model to Distinguish Between Stock and Foreign Exchange Markets, WP07-01

\section{6}

1. Roman Kozhan, Multiple Priors and No-Transaction Region, WP06-24

2. Martin Ellison, Lucio Sarno and Jouko Vilmunen, Caution and Activism? Monetary Policy Strategies in an Open Economy, WP06-23

3. Matteo Marsili and Giacomo Raffaelli, Risk bubbles and market instability, WP06-22

4. Mark Salmon and Christoph Schleicher, Pricing Multivariate Currency Options with Copulas, WP06-21 
5. Thomas Lux and Taisei Kaizoji, Forecasting Volatility and Volume in the Tokyo Stock Market: Long Memory, Fractality and Regime Switching, WP06-20

6. Thomas Lux, The Markov-Switching Multifractal Model of Asset Returns: GMM Estimation and Linear Forecasting of Volatility, WP06-19

7. Peter Heemeijer, Cars Hommes, Joep Sonnemans and Jan Tuinstra, Price Stability and Volatility in Markets with Positive and Negative Expectations Feedback: An Experimental Investigation, WP06-18

8. Giacomo Raffaelli and Matteo Marsili, Dynamic instability in a phenomenological model of correlated assets, WP06-17

9. Ginestra Bianconi and Matteo Marsili, Effects of degree correlations on the loop structure of scale free networks, WP06-16

10. Pietro Dindo and Jan Tuinstra, A Behavioral Model for Participation Games with Negative Feedback, WP06-15

11. Ceek Diks and Florian Wagener, A weak bifucation theory for discrete time stochastic dynamical systems, WP06-14

12. Markus Demary, Transaction Taxes, Traders' Behavior and Exchange Rate Risks, WP06-13

13. Andrea De Martino and Matteo Marsili, Statistical mechanics of socio-economic systems with heterogeneous agents, WP06-12

14. William Brock, Cars Hommes and Florian Wagener, More hedging instruments may destabilize markets, WP06-11

15. Ginwestra Bianconi and Roberto Mulet, On the flexibility of complex systems, WP06-10

16. Ginwestra Bianconi and Matteo Marsili, Effect of degree correlations on the loop structure of scale-free networks, WP06-09

17. Ginwestra Bianconi, Tobias Galla and Matteo Marsili, Effects of Tobin Taxes in Minority Game Markets, WP06-08

18. Ginwestra Bianconi, Andrea De Martino, Felipe Ferreira and Matteo Marsili, Multi-asset minority games, WP06-07

19. Ba Chu, John Knight and Stephen Satchell, Optimal Investment and Asymmetric Risk for a Large Portfolio: A Large Deviations Approach, WP06-06

20. Ba Chu and Soosung Hwang, The Asymptotic Properties of AR(1) Process with the Occasionally Changing AR Coefficient, WP06-05

21. Ba Chu and Soosung Hwang, An Asymptotics of Stationary and Nonstationary AR(1) Processes with Multiple Structural Breaks in Mean, WP06-04

22. Ba Chu, Optimal Long Term Investment in a Jump Diffusion Setting: A Large Deviation Approach, WP06-03

23. Mikhail Anufriev and Gulio Bottazzi, Price and Wealth Dynamics in a Speculative Market with Generic Procedurally Rational Traders, WP06-02

24. Simonae Alfarano, Thomas Lux and Florian Wagner, Empirical Validation of Stochastic Models of Interacting Agents: A "Maximally Skewed" Noise Trader Model?, WP06-01

\section{5}

1. Shaun Bond and Soosung Hwang, Smoothing, Nonsynchronous Appraisal and CrossSectional Aggreagation in Real Estate Price Indices, WP05-17

2. Mark Salmon, Gordon Gemmill and Soosung Hwang, Performance Measurement with Loss Aversion, WP05-16

3. Philippe Curty and Matteo Marsili, Phase coexistence in a forecasting game, WP05-15

4. Matthew Hurd, Mark Salmon and Christoph Schleicher, Using Copulas to Construct Bivariate Foreign Exchange Distributions with an Application to the Sterling Exchange Rate Index (Revised), WP05-14

5. Lucio Sarno, Daniel Thornton and Giorgio Valente, The Empirical Failure of the Expectations Hypothesis of the Term Structure of Bond Yields, WP05-13

6. Lucio Sarno, Ashoka Mody and Mark Taylor, A Cross-Country Financial Accelorator: Evidence from North America and Europe, WP05-12

7. Lucio Sarno, Towards a Solution to the Puzzles in Exchange Rate Economics: Where Do We Stand?, WP05-11

8. James Hodder and Jens Carsten Jackwerth, Incentive Contracts and Hedge Fund Management, WP05-10

9. James Hodder and Jens Carsten Jackwerth, Employee Stock Options: Much More Valuable Than You Thought, WP05-09 
10. Gordon Gemmill, Soosung Hwang and Mark Salmon, Performance Measurement with Loss Aversion, WP05-08

11. George Constantinides, Jens Carsten Jackwerth and Stylianos Perrakis, Mispricing of S\&P 500 Index Options, WP05-07

12. Elisa Luciano and Wim Schoutens, A Multivariate Jump-Driven Financial Asset Model, WP0506

13. Cees Diks and Florian Wagener, Equivalence and bifurcations of finite order stochastic processes, WP05-05

14. Devraj Basu and Alexander Stremme, CAY Revisited: Can Optimal Scaling Resurrect the (C)CAPM?, WP05-04

15. Ginwestra Bianconi and Matteo Marsili, Emergence of large cliques in random scale-free networks, WP05-03

16. Simone Alfarano, Thomas Lux and Friedrich Wagner, Time-Variation of Higher Moments in a Financial Market with Heterogeneous Agents: An Analytical Approach, WP05-02

17. Abhay Abhayankar, Devraj Basu and Alexander Stremme, Portfolio Efficiency and Discount Factor Bounds with Conditioning Information: A Unified Approach, WP05-01

\section{4}

1. Xiaohong Chen, Yanqin Fan and Andrew Patton, Simple Tests for Models of Dependence Between Multiple Financial Time Series, with Applications to U.S. Equity Returns and Exchange Rates, WP04-19

2. Valentina Corradi and Walter Distaso, Testing for One-Factor Models versus Stochastic Volatility Models, WP04-18

3. Valentina Corradi and Walter Distaso, Estimating and Testing Sochastic Volatility Models using Realized Measures, WP04-17

4. Valentina Corradi and Norman Swanson, Predictive Density Accuracy Tests, WP04-16

5. Roel Oomen, Properties of Bias Corrected Realized Variance Under Alternative Sampling Schemes, WP04-15

6. Roel Oomen, Properties of Realized Variance for a Pure Jump Process: Calendar Time Sampling versus Business Time Sampling, WP04-14

7. Richard Clarida, Lucio Sarno, Mark Taylor and Giorgio Valente, The Role of Asymmetries and Regime Shifts in the Term Structure of Interest Rates, WP04-13

8. Lucio Sarno, Daniel Thornton and Giorgio Valente, Federal Funds Rate Prediction, WP04-12

9. Lucio Sarno and Giorgio Valente, Modeling and Forecasting Stock Returns: Exploiting the Futures Market, Regime Shifts and International Spillovers, WP04-11

10. Lucio Sarno and Giorgio Valente, Empirical Exchange Rate Models and Currency Risk: Some Evidence from Density Forecasts, WP04-10

11. Ilias Tsiakas, Periodic Stochastic Volatility and Fat Tails, WP04-09

12. Ilias Tsiakas, Is Seasonal Heteroscedasticity Real? An International Perspective, WP04-08

13. Damin Challet, Andrea De Martino, Matteo Marsili and Isaac Castillo, Minority games with finite score memory, WP04-07

14. Basel Awartani, Valentina Corradi and Walter Distaso, Testing and Modelling Market Microstructure Effects with an Application to the Dow Jones Industrial Average, WP04-06

15. Andrew Patton and Allan Timmermann, Properties of Optimal Forecasts under Asymmetric Loss and Nonlinearity, WP04-05

16. Andrew Patton, Modelling Asymmetric Exchange Rate Dependence, WP04-04

17. Alessio Sancetta, Decoupling and Convergence to Independence with Applications to Functional Limit Theorems, WP04-03

18. Alessio Sancetta, Copula Based Monte Carlo Integration in Financial Problems, WP04-02

19. Abhay Abhayankar, Lucio Sarno and Giorgio Valente, Exchange Rates and Fundamentals: Evidence on the Economic Value of Predictability, WP04-01

\section{2}

1. Paolo Zaffaroni, Gaussian inference on Certain Long-Range Dependent Volatility Models, WP02-12

2. Paolo Zaffaroni, Aggregation and Memory of Models of Changing Volatility, WP02-11

3. Jerry Coakley, Ana-Maria Fuertes and Andrew Wood, Reinterpreting the Real Exchange Rate - Yield Diffential Nexus, WP02-10 
4. Gordon Gemmill and Dylan Thomas, Noise Training, Costly Arbitrage and Asset Prices: evidence from closed-end funds, WP02-09

5. Gordon Gemmill, Testing Merton's Model for Credit Spreads on Zero-Coupon Bonds, WP0208

6. George Christodoulakis and Steve Satchell, On th Evolution of Global Style Factors in the MSCI Universe of Assets, WP02-07

7. George Christodoulakis, Sharp Style Analysis in the MSCI Sector Portfolios: A Monte Caro Integration Approach, WP02-06

8. George Christodoulakis, Generating Composite Volatility Forecasts with Random Factor Betas, WP02-05

9. Claudia Riveiro and Nick Webber, Valuing Path Dependent Options in the Variance-Gamma Model by Monte Carlo with a Gamma Bridge, WP02-04

10. Christian Pedersen and Soosung Hwang, On Empirical Risk Measurement with Asymmetric Returns Data, WP02-03

11. Roy Batchelor and Ismail Orgakcioglu, Event-related GARCH: the impact of stock dividends in Turkey, WP02-02

12. George Albanis and Roy Batchelor, Combining Heterogeneous Classifiers for Stock Selection, WP02-01

\section{1}

1. Soosung Hwang and Steve Satchell, GARCH Model with Cross-sectional Volatility; GARCHX Models, WP01-16

2. Soosung Hwang and Steve Satchell, Tracking Error: Ex-Ante versus Ex-Post Measures, WP01-15

3. Soosung Hwang and Steve Satchell, The Asset Allocation Decision in a Loss Aversion World, WP01-14

4. Soosung Hwang and Mark Salmon, An Analysis of Performance Measures Using Copulae, WP01-13

5. Soosung Hwang and Mark Salmon, A New Measure of Herding and Empirical Evidence, WP01-12

6. Richard Lewin and Steve Satchell, The Derivation of New Model of Equity Duration, WP0111

7. Massimiliano Marcellino and Mark Salmon, Robust Decision Theory and the Lucas Critique, WP01-10

8. Jerry Coakley, Ana-Maria Fuertes and Maria-Teresa Perez, Numerical Issues in Threshold Autoregressive Modelling of Time Series, WP01-09

9. Jerry Coakley, Ana-Maria Fuertes and Ron Smith, Small Sample Properties of Panel Timeseries Estimators with I(1) Errors, WP01-08

10. Jerry Coakley and Ana-Maria Fuertes, The Felsdtein-Horioka Puzzle is Not as Bad as You Think, WP01-07

11. Jerry Coakley and Ana-Maria Fuertes, Rethinking the Forward Premium Puzzle in a Nonlinear Framework, WP01-06

12. George Christodoulakis, Co-Volatility and Correlation Clustering: A Multivariate Correlated ARCH Framework, WP01-05

13. Frank Critchley, Paul Marriott and Mark Salmon, On Preferred Point Geometry in Statistics, WP01-04

14. Eric Bouyé and Nicolas Gaussel and Mark Salmon, Investigating Dynamic Dependence Using Copulae, WP01-03

15. Eric Bouyé, Multivariate Extremes at Work for Portfolio Risk Measurement, WP01-02

16. Erick Bouyé, Vado Durrleman, Ashkan Nikeghbali, Gael Riboulet and Thierry Roncalli, Copulas: an Open Field for Risk Management, WP01-01

\section{0}

1. Soosung Hwang and Steve Satchell, Valuing Information Using Utility Functions, WP00-06

2. Soosung Hwang, Properties of Cross-sectional Volatility, WP00-05

3. Soosung Hwang and Steve Satchell, Calculating the Miss-specification in Beta from Using a Proxy for the Market Portfolio, WP00-04

4. Laun Middleton and Stephen Satchell, Deriving the APT when the Number of Factors is Unknown, WP00-03 
5. George A. Christodoulakis and Steve Satchell, Evolving Systems of Financial Returns: AutoRegressive Conditional Beta, WP00-02

6. Christian S. Pedersen and Stephen Satchell, Evaluating the Performance of Nearest Neighbour Algorithms when Forecasting US Industry Returns, WP00-01

\section{9}

1. Yin-Wong Cheung, Menzie Chinn and Ian Marsh, How do UK-Based Foreign Exchange Dealers Think Their Market Operates?, WP99-21

2. Soosung Hwang, John Knight and Stephen Satchell, Forecasting Volatility using LINEX Loss Functions, WP99-20

3. Soosung Hwang and Steve Satchell, Improved Testing for the Efficiency of Asset Pricing Theories in Linear Factor Models, WP99-19

4. Soosung Hwang and Stephen Satchell, The Disappearance of Style in the US Equity Market, WP99-18

5. Soosung Hwang and Stephen Satchell, Modelling Emerging Market Risk Premia Using Higher Moments, WP99-17

6. Soosung Hwang and Stephen Satchell, Market Risk and the Concept of Fundamental Volatility: Measuring Volatility Across Asset and Derivative Markets and Testing for the Impact of Derivatives Markets on Financial Markets, WP99-16

7. Soosung Hwang, The Effects of Systematic Sampling and Temporal Aggregation on Discrete Time Long Memory Processes and their Finite Sample Properties, WP99-15

8. Ronald MacDonald and Ian Marsh, Currency Spillovers and Tri-Polarity: a Simultaneous Model of the US Dollar, German Mark and Japanese Yen, WP99-14

9. Robert Hillman, Forecasting Inflation with a Non-linear Output Gap Model, WP99-13

10. Robert Hillman and Mark Salmon, From Market Micro-structure to Macro Fundamentals: is there Predictability in the Dollar-Deutsche Mark Exchange Rate?, WP99-12

11. Renzo Avesani, Giampiero Gallo and Mark Salmon, On the Evolution of Credibility and Flexible Exchange Rate Target Zones, WP99-11

12. Paul Marriott and Mark Salmon, An Introduction to Differential Geometry in Econometrics, WP99-10

13. Mark Dixon, Anthony Ledford and Paul Marriott, Finite Sample Inference for Extreme Value Distributions, WP99-09

14. Ian Marsh and David Power, A Panel-Based Investigation into the Relationship Between Stock Prices and Dividends, WP99-08

15. Ian Marsh, An Analysis of the Performance of European Foreign Exchange Forecasters, WP99-07

16. Frank Critchley, Paul Marriott and Mark Salmon, An Elementary Account of Amari's Expected Geometry, WP99-06

17. Demos Tambakis and Anne-Sophie Van Royen, Bootstrap Predictability of Daily Exchange Rates in ARMA Models, WP99-05

18. Christopher Neely and Paul Weller, Technical Analysis and Central Bank Intervention, WP9904

19. Christopher Neely and Paul Weller, Predictability in International Asset Returns: A Reexamination, WP99-03

20. Christopher Neely and Paul Weller, Intraday Technical Trading in the Foreign Exchange Market, WP99-02

21. Anthony Hall, Soosung Hwang and Stephen Satchell, Using Bayesian Variable Selection Methods to Choose Style Factors in Global Stock Return Models, WP99-01

\section{8}

1. Soosung Hwang and Stephen Satchell, Implied Volatility Forecasting: A Compaison of Different Procedures Including Fractionally Integrated Models with Applications to UK Equity Options, WP98-05

2. Roy Batchelor and David Peel, Rationality Testing under Asymmetric Loss, WP98-04

3. Roy Batchelor, Forecasting T-Bill Yields: Accuracy versus Profitability, WP98-03

4. Adam Kurpiel and Thierry Roncalli, Option Hedging with Stochastic Volatility, WP98-02

5. Adam Kurpiel and Thierry Roncalli, Hopscotch Methods for Two State Financial Models, WP98-01 